illness, at which time she had a titre of HAAb consistent with recent infection. Another patient (case 8), in whom the level of $\mathrm{HAAb}$ did not rise significantly between days 13 and 29 of illness, had received an injection of human normal immunoglobulin 10 days before the onset of symptoms, which may have caused a modified antibody response.

Two studies of sporadic non-B hepatitis have been reported recently. In the first a highly selected group of patients was tested, and infection with hepatitis A virus was confirmed in only two out of 73 patients. ${ }^{4}$ The second study, which was carried out prospectively in Los Angeles, found only $48 \%$ of sporadic non-B hepatitis to be type A (J L Dienstag et al, personal communication) and suggested that the remaining cases may have been due to other, as yet unidentified, viruses. In Melbourne infection with hepatitis A virus was confirmed in seven of the eight patients with sporadic disease, but the small number of patients studied makes it impossible to draw firm conclusions about the prevalence of non-A non-B hepatitis. The patient in whom hepatitis $\mathrm{A}$ was not diagnosed had a rising titre of complement fixation antibody to cytomegalovirus.

Until 1971 hepatitis B was uncommon in Melbourne, ${ }^{11}$ and second attacks of hepatitis were almost unknown. ${ }^{12}$ In the last two years, however, several patients (usually intravenous drug users) have been admitted with second and even third attacks. Each of the two such patients studied was found to have had one attack of hepatitis B, and one had had an attack of hepatitis A. The remaining episode of hepatitis was not diagnosed. HAAb was not detected in acute and convalescent serum samples and no evidence was obtained of infection with other viral, bacterial, or rickettsial agents known to produce acute liver damage. Possibly this illness may have been due to a hepatitis virus other than A or B.

The antibody response to hepatitis A virus, detected by immune adherence haemagglutination, was similar to that described in a group of patients who developed hepatitis after eating contaminated shellfish. ${ }^{7} \mathrm{HAAb}$ was not detected in sera collected during the first week after the onset of symptoms and was detected in only three of the 12 sera collected during the second week. In most patients antibody was first detected in the third or fourth week after the onset of symptoms, then rose in titre, peaking in the eighth or ninth week. No substantial data on the duration of antibody were obtained, but in two patients from whom sera were obtained at 210 days and 217 days no fall in titre had occurred.

Our results confirm that the detection of rising titres of HAAb by immune adherence haemagglutination is a reliable index of infection with the hepatitis $A$ virus and that the presence of antibody in high titre during the first two weeks of illness or its absence in sera collected six weeks or more after the onset of symptoms makes a diagnosis of hepatitis A unlikely.

The authors wish to thank Mrs Doris Wong and Mrs Mary Dimitrakakis for excellent technical help. This study was assisted by a grant from the National Health and Medical Research Council of Australia.

Requests for reprints should be addressed to Dr I D Gust, Department of Virology, Fairfield Hospital for Communicable Diseases, Fairfield, Victoria 3078, Australia.

\section{References}

${ }^{1}$ Feinstone, S M, Kapikian, A Z, and Purcell, R H, Science, 1973, 182, 1026.

2 Provost, P J, et al, Proceedings of the Society for Experimental Biology and Medicine, 1975, 148, 962.

${ }^{3}$ Miller, W J, et al, Proceedings of the Society for Experimental Biology and Medicine, 1975, 149, 254.

${ }^{4}$ Purcell, R H, et al, American fournal of Medical Science, 1975, 270, 61.

5 Dienstag, J L, et al, Annals of Internal Medicine, 1975, 83, 647.

${ }^{6}$ Gravelle, C R, et al, fournal of Infectious Diseases, 1975, 131, 167.

${ }^{7}$ Dienstag, J L, et al, Lancet, 1976, 1, 561

${ }^{8}$ Ling, C M, and Overby, L R, fournal of Immunology, 1972, 109, 834.

Lehmann, N I, and Gust, I D, in Hepatitis B, ed G E Logan, p 173. Sydney, Electric Press, 1975.

${ }^{10}$ Moritsugu, Y, et al, Infection and Immunity, 1976, 13, 898.

11 Gust, I D, Australia and New Zealand Fournal of Medicine, 1974, 4, 548.

12 Medical fournal of Australia, 1967, 2, 559.

(Accepted 22 November 1976)

\title{
Rheumatoid arthritis: relation of serum C-reactive protein and erythrocyte sedimentation rates to radiographic changes
}

\author{
R S AMOS, T J CONSTABLE, R A CROCKSON, A P CROCKSON, B MCCONKEY
}

British Medical fournal, 1977, 1, 195-197

\section{Summary}

Serum $C$ reactive protein $(C R P)$ levels and erythrocyte sedimentation rates (ESR) were measured in 56 patients with rheumatoid arthritis. Radiographical damage,

Dudley Road Hospital, Birmingham B18 7QH

R S AMOS, BSC, MRCP, Sheldon clinical research fellow

$T$ J CONSTABLE, MB, MRCP, Sheldon clinical research fellow (now senior registrar, Northern General Hospital, Edinburgh)

Department of Experimental Pathology, University of Birmingham, Birmingham B15 2TJ

R A CROCKSON, FIMLS, technical superintendent

A P CROCKSON, FIMLS, senior chief technician

B MCCONKEY, DM, FRCP, consultant physician and honorary research fellow

based on a count of erosions, was significantly more likely to occur when serum CRP and ESR were persistently raised, irrespective of the presence or absence of rheumatoid factor. Measurements of both CRP and ESR were more helpful than either alone, but CRP was probably the more informative. Serial measurements of CRP and ESR provide a reliable means of discriminating between drugs that provide symptomatic relief only and those with a more profound effect in rheumatoid arthritis.

\section{Introduction}

The acute-phase reactants are a class of serum proteins, mainly glycoproteins, whose concentration in the blood increases after various stimuli such as trauma or inflammation. ${ }^{1}$ The magnitude of the acute-phase protein response is roughly proportional to the severity of the stimulus. ${ }^{2}{ }^{3}$ Serial measurements of these proteins can therefore be used, like the erythrocyte sedimenta- 
tion rate (ESR), which is largely a measure of fibrinogen, ${ }^{4}$ to monitor the progress of an inflammatory disorder.

We have discussed the use of serial measurements of two of these proteins, $C$ reactive protein (CRP) and haptoglobin, in rheumatoid arthritis. ${ }^{5}$ Serial measurements are attractive for several reasons: they reflect the clinical course of the disease over periods up to three years and are objective, simple, and easy to record. Unlike some other methods, such as measuring finger joint size, thermography, technetium clearance, or the articular index, ${ }^{6}$ they are unaffected by aspirin and similar drugs, ${ }^{7}$ which have a temporary, local, anti-inflammatory action but are not thought to have any effect on the course of the disease. ${ }^{8}$ The acute-phase protein response is not specific to rheumatoid arthritis, however, so that a confirmation of its usefulness through comparison with a more direct indication of the progress of the disease would increase confidence in the method. We therefore compared the progression of rheumatoid arthritis as judged by radiographic changes with levels of serum CRP and the ESR.

\section{Patients and methods}

We studied 56 patients with definite or classical rheumatoid arthritis ${ }^{9}$ selected from a bank of data on 400 patients. They were all those whose serum CRP and ESR, measured every six to eight weeks, remained within one of five ranges (table I) over a period of at least 12 months regardless of treatment. The ranges were chosen on the basis of previous findings. ${ }^{5}$

TABLE I-Criteria for selecting groups of patients

\begin{tabular}{|c|c|c|c|}
\hline Group & CRP and ESR characteristics & $\mathrm{CRP}(\mathrm{mg} / \mathrm{l})$ & $\operatorname{ESR}(\mathrm{mm}$ in $1 \mathrm{~h})$ \\
\hline $\begin{array}{l}1 \\
2 \\
3 \\
4 \\
5\end{array}$ & $\begin{array}{l}\text { Low values } \\
\text { Intermediate values } \\
\text { High values } \\
\text { High CRP; low ESR } \\
\text { Low CRP; high ESR }\end{array}$ & $\begin{array}{l}<40 \\
40-100 \\
>100 \\
>40 \\
<40\end{array}$ & $\begin{array}{r}<30 \\
30-60 \\
>60 \\
<30 \\
>30\end{array}$ \\
\hline
\end{tabular}

Anteroposterior radiographs of both hands and wrists were made yearly and assessed according to the number of bone erosions. The total number of yearly comparisons (86) exceeded the number of patients because some people remained in their group for longer than a year. The radiograph observers were not aware of the CRP and ESR values. $\chi^{2}$ analysis was used to assess the results, and Yates's correction was applied.

\section{Results}

The characteristics of the five groups are shown in table II. They were well matched for age. Duration of rheumatoid arthritis varied widely, being longest in group 1. The proportion with a positive result on the Rose-Waaler test was roughly the same in all groups except group 4.

Table III shows the radiological extent of the disease at the first assessment. There was no consistent pattern, but a high proportion of patients in group 2 had more than 10 erosions. Subsequent yearly radiographs showed (table IV) that no patient in group 1 (CRP $<40$ $\mathrm{mg} / \mathrm{l}$; ESR $<30 \mathrm{~mm}$ in $1 \mathrm{~h}$ ) had developed more than three new

TABLE II-Characteristics of each group of patients

\begin{tabular}{|c|c|c|c|c|c|c|}
\hline Group & $\begin{array}{c}\text { No of } \\
\text { patients }\end{array}$ & $\begin{array}{c}\text { No positive } \\
\text { on } \\
\text { Rose-Waaler } \\
\text { test }\end{array}$ & $\begin{array}{c}\text { Mean } \\
\text { age } \\
\text { (years) }\end{array}$ & $\begin{array}{c}\text { Mean } \\
\text { duration } \\
\text { of } \\
\text { disease } \\
\text { (years) }\end{array}$ & $\underset{(\mathbf{m g} / \mathbf{l})}{\operatorname{Mean}( \pm \mathrm{P}} \mathrm{SE})$ & $\begin{array}{c}\underset{\text { ESR }}{\operatorname{Mean}}( \pm \mathrm{SE}) \\
(\mathrm{mm} \text { in } 1 \mathrm{~h})\end{array}$ \\
\hline $\begin{array}{l}1 \\
2 \\
3 \\
4 \\
5\end{array}$ & $\begin{array}{r}11 \\
12 \\
11 \\
16 \\
6\end{array}$ & $\begin{array}{r}8 \\
11 \\
8 \\
11 \\
5\end{array}$ & $\begin{array}{l}57 \\
54 \\
52 \\
50 \\
47\end{array}$ & $\begin{array}{l}10 \\
8 \cdot 3 \\
6 \cdot 8 \\
7 \cdot 7 \\
5 \cdot 7\end{array}$ & $\begin{aligned} 15 & \pm 10 \\
88 & \pm 20 \\
185 & \pm 93 \\
71 & \pm 34 \\
12 & \pm 9\end{aligned}$ & $\begin{array}{l}15 \pm 8 \\
49 \pm 15 \\
83 \pm 25 \\
17 \pm 5 \\
48 \pm 20\end{array}$ \\
\hline
\end{tabular}

TABLE III-Radiological extent of joint damage in hands and wrists at beginning of study

\begin{tabular}{c|c|c|c|c}
\hline \multirow{2}{*}{ Group } & $\begin{array}{c}\text { No of } \\
\text { patients }\end{array}$ & \multicolumn{2}{c}{ Erosions } \\
\cline { 3 - 4 } & & $<6$ & $6-10$ & $>10$ \\
\hline 1 & 11 & 6 & 3 & 2 \\
2 & 12 & 2 & 2 & 8 \\
3 & 11 & 4 & 5 & 5 \\
4 & 16 & 8 & 2 & 2 \\
\hline
\end{tabular}

TABLE IV-Radiological progression of joint damage in hands and wrists

\begin{tabular}{|c|c|c|c|c|}
\hline \multirow{2}{*}{ Group } & \multirow{2}{*}{$\begin{array}{c}\text { No of } \\
\text { assessments }\end{array}$} & \multicolumn{3}{|c|}{ New erosions/year } \\
\hline & & $<4$ & $4-6$ & $>6$ \\
\hline $\begin{array}{l}1 \\
2 \\
3 \\
4 \\
5\end{array}$ & $\begin{array}{l}15 \\
12 \\
15 \\
32 \\
12\end{array}$ & $\begin{array}{r}15 \\
3 \\
1 \\
17 \\
8\end{array}$ & $\begin{array}{r}0 \\
4 \\
6 \\
11 \\
3\end{array}$ & $\begin{array}{l}0 \\
5 \\
8 \\
4 \\
1\end{array}$ \\
\hline
\end{tabular}

erosions in any year. All but one patient in group 3 (CRP $>100 \mathrm{mg} / \mathrm{l}$; ESR $>60 \mathrm{~mm}$ in $1 \mathrm{~h}$ ) developed four or more new erosions each year and in over half there were more than six new erosions. Group showed intermediate results. The differences between groups 1,2 , and 3 were significant $(P<0.001)$. To ensure that the expected frequency in each cell of the $\chi^{2}$ table was more than five the analysis was repeated after pooling the observations for four to six and more than six erosions in each group. The result was still significant $(P<0.001)$.

When there was a high serum CRP level but low ESR (group 4) four or more new erosions developed each year in 15 out of $32\left(47^{\circ} \%\right)$ assessments; when there was a low CRP level but high ESR (group 5) four or more new erosions per year appeared in four of the $12(33 \%)$ assessments. The difference was not significant. Patients in group 4 were significantly more likely to develop erosions than those in group 1 $(P<0.01)$; differences between groups 1 and 5 could not be tested as the numbers were too small.

There was no difference in radiological progression in each group between patients who gave positive responses on the Rose-Waaler test $(\geqslant 1 / 16)$ and those with negative responses. In positive patients four or more new erosions were seen in $48 \%$ of comparisons and $22 \%$ showed more than six new erosions. The figures in negative patients were $50^{\circ}$ and $17 \%$ respectively.

\section{Discussion}

The results confirmed the usefulness of serial measurements of CRP and ESR for assessing the progress of rheumatoid arthritis, ${ }^{510}$ and the correlation may now be extended to include $x$-ray changes. When CRP and ESR levels were low no patient showed radiographic evidence of progression of the disease whatever its previous severity. In contrast, when the levels were high nearly all patients deteriorated. This relation was independent of the presence of rheumatoid factor. It is believed that patients with a positive Rose-Waaler response are more likely to develop bone erosions than those with a negative response, but it is difficult to reconcile this view with our results. Our patients were not selected according to their Rose-Waaler reaction and this may explain the discrepancy.

Although the CRP and ESR usually run similar courses there were several people who had high CRP levels with a low ESR; they showed more erosive progression than would have been expected on the basis of the ESR. The same could be said, but with less confidence, of patients with a raised ESR but low CRP. The ESR depends on several variables, ${ }^{11}{ }^{12}$ whereas CRP is a discrete entity and can be measured accurately by immunodiffusion. ${ }^{1314}$ In our experience an unexpectedly low ESR is far more common than an unexpectedly low CRP. Though estimations of both are therefore better than either alone, CRP is probably more informative. Haptoglobin was not measured in this study because, unlike CRP and the ESR, it has a wide 
variation in normal range. Consequently the clinical significance of a particular level of haptoglobin is less important than change from that level. In general changes in haptoglobin levels correlate with changes in CRP and ESR. ${ }^{2} 3$;

All groups contained patients with a wide range of radiological damage at the onset of the study but we cannot say what the CRP and ESR levels had been during the development of that damage. The mere presence of joint erosions apparently does not itself raise CRP and ESR levels. Several methods of assessing radiographic changes have been described, some of them extremely detailed. Sharp, ${ }^{15}$ for example, gave a possible score of 290 for each hand based on joint space, juxta-articular osteoporosis, soft tissue changes, and erosions. Some of these are particularly difficult to assess. Counting all clear-cut erosions in the hands and wrists seemed to provide a simple and practical alternative. Possibly other joints may have been damaged, but it is unusual for a patient with widespread rheumatoid arthritis to have little or no evidence of disease in the hands or wrists.

Our findings may help to explain the different effects of different drugs. Only drugs capable of lowering acute-phase protein levels could be expected to have any effect on the evolution of $x$-ray changes. Even then CRP and ESR levels would have to be substantially reduced for at least a year before any such effect could be recognised in an individual; in groups of patients with variable responses to a drug recognising an effect would be more difficult.
Regional Health Authority to this work. Dr J Egginton gave valuable advice in the early stages.

\section{References}

${ }^{1}$ Soothill, J F, Lectures on the Scientific Basic of Medicine, p 276. London, Athlone Press, 1967.

2 Aronsen, K F, et al, Scandinavian fournal of Clinical and Laboratory Investigation, 1972, 20, suppl No $124, \mathrm{p} 124$.

${ }^{3} \mathrm{Koj}, \mathrm{A}$, in Structure and Function of Plasma Proteins, vol 1, ed A C Allison, $p$ 73. London and New York, Plenum Press, 1974.

${ }^{4}$ Hardwicke, J, and Squire, J R, Clinical Science, 1952, 2, 333.

${ }^{5}$ McConkey, B, Crockson, R A, and Crockson, A P, Quarterly fournal of Medicine (New Series), 1972, 41, 115.

${ }^{6}$ Ritchie, D M, et al, Quarterly fournal of Medicine (New Series), 1968, 37, 393.

' McConkey, B, et al, Quarterly fournal of Medicine (New Series), 1973, 42, 785.

${ }^{8}$ Paulus, H E, and Whitehouse, M W, Search for New Drugs, ed A A Rubin, p 1. New York, Marcel Decker, 1972.

${ }^{9}$ American Rheumatism Association, Annals of the Rheumatic Diseases, $1959,18,49$.

${ }^{10}$ Constable, T J, et al, Lancet, 1975, 1, 1176

${ }^{11}$ Crockson, R A, and Crockson, A P, Annals of the Rheumatic Diseases, 1974, 33, 53.

${ }_{12}$ Zacharski, L R, British fournal of Hospital Medicine, 1976, 16, 53.

${ }^{13}$ Crockson, R A, Fournal of Clinical Pathology, 1963, 16, 287.

${ }^{14}$ Mancini, G, Carbonata, A O, and Heremans, J F, Immunochemistry, 1965, 2,235 .

${ }^{15}$ Sharp, J T, et al, Arthritis and Rheumatism, 1971, 14, 706.

\title{
Continuous intrauterine copper contraception for 3 years: comparison of replacement at 2 years with continuation of use
}

\author{
JOHN NEWTON, RUTH ILLINGWORTH, JULIAN ELIAS, JOHN MCEWAN
}

British Medical fournal, 1977, 1, 197-199

\section{Summary}

A total of 1245 women who had a copper 7 intrauterine contraceptive device (IUD) inserted in 1971-3 were followed up for three years (22 761.5 women months of use). After 24 months 483 women elected to continue with the same copper 7 (continuation group), and 183 had their copper 7 replaced with a new one (replacement group). The subsequent pregnancy and expulsion rates were both significantly lower in the replacement group. The higher pregnancy rate among the women who continued to use their copper 7 device for a third year suggests that although the copper is still there, it is not available for contraceptive action. Replacing the device at 24 months did not seem to cause again the problems that usually occur in the first six months of IUD use.

\footnotetext{
World Health Organisation Collaborating Centre for Clinical Research and Department of Obstetrics and Gynaecology, King's College Hospital, London SE5

JOHN NEWTON, MD, MRCOG, senior lecturer and director of centre RUTH ILLINGWORTH, SRN, SCM, research nurse

JULIAN ELIAS, MRCOG, WHO research fellow

JOHN MCEWAN, MB, MRCGP, consultant in family planning
}

\section{Introduction}

We have described our results with the copper 7 intrauterine device (IUD). ${ }^{12}$ Recent reports ${ }^{3}$ indicate that the useful life of a copper 7 may be three to four years, while Cooper et al predict an even longer useful life for the copper T $220 \mathrm{C}$. Recent reports of calcium deposition on copper devices, however, throw doubt on this longer life span of copper IUDs. ${ }^{5}$

To investigate the effect of time on the pregnancy rate and other medical side effects, we have collected data from the patients we originally studied ${ }^{2}$ during their third year of using a copper 7 device.

\section{Patients and method of analysis}

All patients who enrolled in the original copper 7 study and continued with the copper 7 were followed for at least 36 months. From January 1971 to March 19731245 women had a copper 7 inserted. When all patients had used the copper 7 for 24 months they were given a choice of continuing with the same device (continuation group) or having the device replaced with a new copper 7 (replacement group). At 1 April 1976 there were 443 women in the continuation group and 183 in the replacement group. All patients were seen each month for the first three months after insertion or replacement and thereafter every three months for three years. Cervical smears were taken every year. Our previous analyses were confined to first segments of use, but this report includes first and subsequent segments of use as described by Tietze $e t \mathrm{al}^{7}$; these reflect the actual use of this copper IUD in clinical practice. 